OPEN ACCESS

Edited by:

Steven M. Kerfoot,

Western University, Canada

Reviewed by:

Nancy H. Ruddle,

Yale University School of Medicine,

USA

Richard Reynolds,

Imperial College London, UK

*Correspondence:

Jennifer L. Gommerman

jen.gommerman@utoronto.ca

Specialty section:

This article was submitted to Multiple Sclerosis and Neuroimmunology,

a section of the journal

Frontiers in Immunology

Received: 14 August 2015 Accepted: 22 December 2015 Published: 13 January 2016

Citation:

Pikor NB, Prat A, Bar-Or A and Gommerman JL (2016) Meningeal

Tertiary Lymphoid Tissues and Multiple Sclerosis: A Gathering Place for Diverse Types of Immune Cells during CNS Autoimmunity.

Front. Immunol. 6:657. doi: 10.3389/fimmu.2015.00657

\section{Meningeal Tertiary Lymphoid Tissues and Multiple Sclerosis: A Gathering Place for Diverse Types of Immune Cells during CNS Autoimmunity}

\author{
Natalia B. Pikor ${ }^{1}$, Alexandre Prat ${ }^{2}$, Amit Bar-Or ${ }^{3}$ and Jennifer L. Gommerman ${ }^{1 *}$ \\ ${ }^{1}$ Department of Immunology, University of Toronto, Toronto, ON, Canada, ${ }^{2}$ Neuroimmunology Unit, Department of \\ Neuroscience, Centre de Recherche de CHUM, Université de Montréal, Montreal, QC, Canada, ${ }^{3}$ Neuroimmunology Unit, \\ Montreal Neurological Institute and Hospital, McGill University, Montreal, QC, Canada
}

Collections of leukocytes in the meningeal space have been documented in Multiple Sclerosis (MS). These meningeal aggregates, which in the context of other autoimmune diseases have often been termed tertiary lymphoid tissues (TLT), have been associated with sub-pial cortical damage and disease progression. However, the key molecular and cellular signals required for their formation and maintenance remain unclear. Herein, we review TLT structures in other disease states in order to provide a framework for understanding these structures in the MS meninges. We then assess the evidence that the meningeal compartment serves as an important nexus for immune cells as well as a location for drainage of antigen into cervical lymph nodes. Extrapolating what is known about the molecular and cellular cues that initiate the formation of leukocyte aggregates in non-lymphoid tissues, we speculate on what signals lead to the formation and maintenance of meningeal TLT structures. Referring to the animal model of MS [experimental autoimmune encephalomyelitis (EAE)], we also explore what is known about these structures in supporting $B$ cell and $T$ cell responses during neuroinflammation. Last, we examine the evidence that connects these structures to ongoing neuropathology. Collectively, our review points to the meningeal compartment as an important player in neuroinflammatory processes. Moreover, we hypothesize that in order to gain insights into pro- and anti-inflammatory properties of lymphocytes in MS, one must understand the cellular scaffolds that support lymphocyte retention within the meninges, thus highlighting the importance of non-immune cells (stromal cells) in the neuroinflammatory process.

Keywords: meninges, multiple sclerosis, experimental autoimmune encephalomyelitis, tertiary lymphoid tissues, stromal cells

\section{OVERVIEW}

Multiple sclerosis (MS) is an inflammatory disease of the central nervous system (CNS) resulting in demyelination and axonal loss with consequential clinical impairment. MS is most commonly diagnosed as relapsing-remitting MS (RRMS), which is thought to reflect the waxing and waning of underlying CNS-targeted immune responses. Most individuals with RRMS go on to develop a 
progressive form of MS, termed secondary progressive MS. The relative absence of new gadolinium-enhancing lesions in the CNS of individuals with progressive MS has for a long-time supported the hypothesis that there is limited infiltration of peripheral immune cells into the CNS at this stage of disease (1). This concept has been recently challenged following the observation of meningeal leukocytic infiltrates (consisting of T cells, B cells, plasma cells, monocytes and macrophages) in both SPMS [in as many as $40 \%$ of cases; (2-4)] and Primary Progressive MS (5), correlating with proximal neuropathology (6). However, meningeal inflammation may also contribute to neuroinflammatory processes early on in MS, and recent MRI studies demonstrate leptomeningeal contrast enhancement in RRMS [ 19\% of cases; (7)].

Meningeal leukocytic aggregates have been referred to as tertiary lymphoid tissues (TLT), provoking the hypothesis that such aggregates support disease-relevant immune responses locally within the CNS. Although there is some discrepancy as to whether meningeal follicle-like structures recapitulate all of the features of TLT, for the purposes of this review, we will refer to them as TLT $(8-10)$.

\section{TERTIARY LYMPHOID TISSUES}

Tertiary lymphoid tissues (TLT) are locally inducible leukocyte aggregates that form in chronically inflamed non-lymphoid tissues and share cellular and organizational similarities with secondary lymphoid organs (SLO). TLT arise within the target tissues of many autoimmune diseases and certain sites of chronic infection, including in the synovial membrane of the joints (rheumatoid arthritis), salivary glands (Sjögren's syndrome), thymus (Mysasthenia gravis and Grave disease), meninges (MS), the liver (hepatitis $\mathrm{C}$ viral infection), the lung (Influenza A viral infection), as well as at sites of chronic graft rejection, atherosclerosis, and cancer $(8,10)$. The majority of information we have on TLT structure and formation is from disease settings that do not involve the CNS. This may be due to the limitations in studying TLT in post-mortem tissue (brain tissue from autopsies tends to be obtained very late in the disease process when inflammation may be less pronounced), the relatively smaller size of meningeal TLT, and variability in histology and dissection protocols for assessing meningeal TLT. As such, this section will focus on what we have learned about TLT in other disease settings that may be more amenable to study, and we will then apply these findings to CNS autoimmunity in a subsequent section.

\section{TLT Structure}

Lymphoid architecture is orchestrated by specialized stromal cell subsets. Follicular dendritic cells (FDC; CD45-CD31-Pdpn ${ }^{ \pm}$) and recently defined Cxcl12-expressing reticular cells (CRC; CD $45^{-} \mathrm{CD} 31^{-} \mathrm{Pdpn}^{ \pm}$) (11) secrete $\mathrm{B}$ cell chemoattractants CXCL13 and CXCL12, respectively. FDC further upregulate molecules involved in trapping and presenting antigen (CD35, FDC-M1, and FDC-M2) to support germinal center responses. The $\mathrm{T}$ cell zone is supported by fibroblastic reticular cells (FRC; $\mathrm{CD}^{-} 5^{-} \mathrm{Pdpn}^{+} \mathrm{CD} 31^{-}$) that secrete $\mathrm{T}$ cell chemoattractants (CCL19, CCL21) as well as T and B cell survival factors (IL-7, BAFF) and form long reticular channels supporting the passage of antigen through the lymphoid organ (12). TLT encompass a spectrum of lymphoid tissue-like organization depending on the target tissue. TLT are primarily described as B cell-rich infiltrates, with a varying degree of $\mathrm{T}$ cell infiltration and sometimes segregation into distinct B and T cell compartments resembling SLO architecture. Although FDC markers have been detected within TLT in various chronic inflammatory conditions, not all TLT demonstrate germinal centers or reticular conduits reminiscent of FRC $(10,13$, 14). Mature TLT can also contain high endothelial venules (HEV) and lymphatic vessels, suggesting an avenue for entry of naive lymphocytes (via the HEV) and egress of antigen and activated or memory lymphocytes via lymphatic vessels (15).

\section{TLT Formation}

Lymphorganogenesis requires the well-defined interaction of embryonic/neonatal lymphoid tissue inducer cells (LTi; $\mathrm{CD} 5^{+} \mathrm{CD}^{+} \mathrm{CD}^{-}$) with stromal lymphoid tissue organizer cells (LTo) to promote LTo maturation into specialized lymphoid stromal cells that in turn form an immune-competent niche [reviewed by Ref. $(12,16-20)]$. In the context of lymphoneogenesis in the adult host, distinct cell types may substitute as TLT inducer and organizer cells. LTi equivalent cell types implicated in TLT formation include: innate lymphoid cells (21-23), T cells (24-27), NKT cells $(28)$, as well a myeloid cells $(28,29)$. Although the exact combination of molecular cues may differ, a unifying feature of TLT-inducing leukocytes is their production of cytokines, especially IL-17 [reviewed by Ref. (30)] and/or IL-22 (21, 22, 27), and their ability to engage receptors of the Tumor Necrosis Factor (TNF) superfamily (LT $\beta$ R, TNFR) by virtue of their expression of cognate ligands $\mathrm{LT} \alpha \beta$ and TNF $\alpha$.

The origin and phenotype of TLT organizer cells remains more elusive. Seminal studies have demonstrated that stromal precursor cells reside quiescently throughout the periphery, and mature to acquire phenotypic and functional capacities consistent with lymphoid tissue stromal cells in response to inflammation $(29,31)$. A population of $\mathrm{CD}^{-} 5^{-} \mathrm{CD} 31^{-} \mathrm{Pdpn}^{-}$cells, which transcriptionally most closely resemble FRCs (32), has also been demonstrated to differentiate into de novo FRCs in the inflamed $\operatorname{LN}(33,34)$, illustrating that even within adult SLOs, mesenchymal precursors can recapitulate an LTo-like function. Nevertheless, further studies are needed in order to elucidate to what extent mesenchymal precursor cells in the adult host resemble embryonic LTos and how such LTo-like cells differentiate in order to support emerging TLT.

Several markers have been useful for assessing the phenotype of tissue-resident stromal cells, including: podoplanin (Pdpn or gp38); the endothelial cell marker, CD31; EPCAM, a marker of epithelial cells; as well as the expression of homeostatic chemokines. For example, in several models of TLT formation, peripheral Pdpn ${ }^{+}$stromal cells express CXCL13 (26, 27, 29, 31), while in a model of atherosclerosis, vascular smooth muscle cells were found to express both CXCL13 and CCL21 within aortic TLT (35). Both Pdpn ${ }^{+} \mathrm{CD} 31^{-}$stromal cells and EPCAM ${ }^{+}$ epithelial cells express CXCL12 within TLT in the lungs (26) and salivary glands (27), respectively. Nevertheless, without a consistent panel of mesenchymal/lymphoid stromal cell markers applied to different models of TLT formation, it is difficult to 
interpret whether different inflammatory insults instigate distinct maturation protocols from ubiquitous precursor cells, or whether tissue-specific differences exist.

In summary, our current understanding is that precursors of lymphoid-like stromal cells reside quiescently throughout peripheral non-lymphoid tissues and are poised to mature into lymphoid stromal cells at sites of persistent inflammation. In response to local inflammatory cues, tissue-resident stromal cells acquire phenotypic and functional capacities consistent with lymphoid tissue stromal cells.

\section{STRUCTURE AND FUNCTION OF MENINGEAL TLT DURING CNS AUTOIMMUNITY}

Meningeal aggregates in the MS CNS are often referred to as TLT; however, as is true for ectopic lymphoid tissues in general, this term captures a range of lymphoid tissue-like organization. Animal studies characterizing meningeal inflammation in EAE demonstrate TLT formation in mice with different genetic backgrounds and disease-induction protocols $(24,36-39)$. These meningeal infiltrates often resemble mature TLT, with the presence of lymphoid-like stromal cells, elaboration of an extra-cellular matrix (ECM) network, and expression of cytokines and homeostatic chemokines. Below, we will review our current understanding about the structure and capacity for the meninges to support TLT formation, as well as the clinical and neuropathological correlates of meningeal TLT in both MS and EAE (see also Table 1).

\section{Anatomical Structure of the Meninges}

The meninges are a series of membranes that envelope the brain and spinal cord, serving as a canal for circulating cerebrospinal fluid (CSF). The outermost membrane is the dura, which cocoons the CNS and is attached to the skull and spinal column. The leptomeninges that envelope the entire CNS consist of the arachnoid and pia mater and are separated by the subarachnoid space. Large conducting blood vessels transecting the leptomeninges are embedded within the pia mater, which is lined by the glial limitans, a barrier comprising astrocytic end-foot processes (55). Cells of the pia mater continue to line intracerebral arteries but gradually become less dense as the arteries penetrate the CNS parenchyma (56-58). The meningeal space is depicted in Figure 1. Cells that reside in the meningeal compartment include fibroblasts and peri-endothelial cells (myofibroblasts, pericytes, and vascular smooth muscle cells), as well as CNS-resident macrophages and dendritic cells. A recent study by Louveau and colleagues has revealed the presence of lymphatic vessels within the dural sinuses, implying there is direct communication between the meningeal environment and the draining cervical LNs (cLN) (59).

\section{The Meninges - A Portal of Leukocyte Entry and Accumulation in the Inflamed CNS}

The blood endothelium transecting the subarachnoid space (the blood-CSF barrier) represents an important route of leukocyte
TABLE 1 | Association of immune cell phenotypes and pathology with TLT.

\begin{tabular}{|c|c|c|}
\hline Feature & Evidence & Reference \\
\hline \multirow{3}{*}{$\begin{array}{l}\text { B cell } \\
\text { responses - EAE }\end{array}$} & B cell-rich meningeal aggregates during & (36) \\
\hline & EAE & $(40)$ \\
\hline & $\begin{array}{l}\text { FDC-M1- and CD35-immunoreactive cells } \\
\text { (FDC-like cells) and CXCL13 transcripts } \\
\text { within meningeal TLT }\end{array}$ & (36) \\
\hline \multirow[t]{6}{*}{ B cell responses - MS } & B cell- and plasma cell-rich meningeal TLT & $\begin{array}{r}(2) \\
(41)\end{array}$ \\
\hline & $\begin{array}{l}\text { CD35- and CXCL13-immunoreactive cells } \\
\text { (FDC-like cells) within meningeal TLT }\end{array}$ & (2) \\
\hline & Activated B cells (clonal expansion, & (42) \\
\hline & somatic hypermutation, Ig class switching) & (43) \\
\hline & within meningeal aggregates & (44) \\
\hline & & (45) \\
\hline \multirow{8}{*}{$\begin{array}{l}\text { T cell } \\
\text { responses - EAE }\end{array}$} & $T$ cells infiltrate the meninges and & (46) \\
\hline & are reactivated in the subarachnoid & $(47)$ \\
\hline & compartment & $(48)$ \\
\hline & & $\begin{array}{l}(49) \\
(50)\end{array}$ \\
\hline & $\begin{array}{l}\text { T cell epitope spreading concurrent with } \\
\text { presence of meningeal TLT }\end{array}$ & (37) \\
\hline & Th17 cells contribute to meningeal TLT & $(51)$ \\
\hline & formation & (24) \\
\hline & & (52) \\
\hline \multirow[t]{3}{*}{ T cell responses - MS } & T cell accumulation within meningeal TLT & (4) \\
\hline & & (53) \\
\hline & & (5) \\
\hline \multirow[t]{13}{*}{ Neuropathology - MS } & Cortical demyelination & $(54)$ \\
\hline & & (3) \\
\hline & & (6) \\
\hline & & (53) \\
\hline & & (4) \\
\hline & & (5) \\
\hline & Glial limitans damage, increased microglial & (3) \\
\hline & activation & (6) \\
\hline & & (4) \\
\hline & & (41) \\
\hline & Cortical astrocyte and oligodendrocyte loss & (6) \\
\hline & Neuronal loss & (6) \\
\hline & & (5) \\
\hline \multirow[t]{2}{*}{ Clinical correlates } & Earlier age of clinical onset, faster time of & (3) \\
\hline & disease progression, earlier age at death & (4) \\
\hline
\end{tabular}

entry into the meninges. In the steady state, the subarachnoid space represents an avenue for immune-surveying lymphocytes to scan the CNS (60). Studies examining the kinetics of meningeal infiltration in EAE report an influx of immune cells prior to clinical onset (39). In addition, using specialized fluorescent reporter mice and two-photon live imaging, myelin-specific $\mathrm{T}$ cells have been shown to first cross the blood-CSF barrier in the subarachnoid space, where antigen-specific re-priming must occur in order to gain access to the parenchyma and instigate clinical symptoms of EAE (47). With respect to MS, biopsies from early stage MS patients identified a subset of patients with evidence of cortical demyelinating lesions associated with meningeal inflammation (53). Moreover, a recent study has estimated that almost $20 \%$ of individuals with RRMS demonstrate meningeal contrast enhancement (7).

EAE studies, post-mortem histological analyses, and CSF samplings all demonstrate that accumulation of proliferating, 


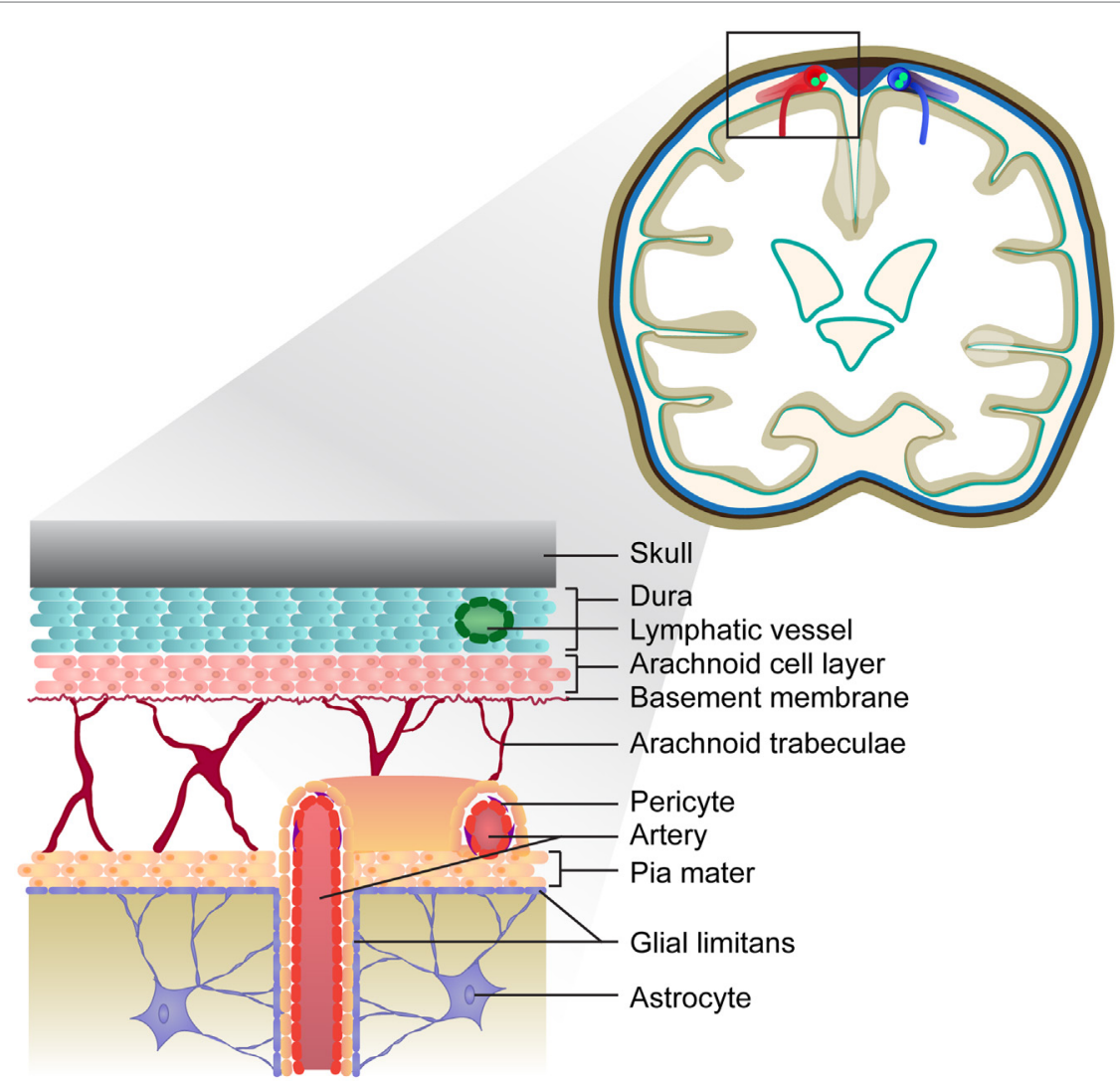

FIGURE 1 | Depiction of the meninges in the healthy brain. The meninges consist of three layers: the dura is the outermost layer, followed by the arachnoid and pia, which form the leptomeninges. Lymphatic vessels embedded within the dura drain the sagittal sinus (not depicted). The vasculature transecting the meninges is embedded within the pial cell layer, and represents a route of leukocyte entry into the CNS.

antigen-experienced T cells $(48,61,62)$, and B cells $(3,4,42-45)$ can occur within the meningeal compartment itself during CNS autoimmunity. In terms of $\mathrm{T}$ cell responses, epitope spreading of myelin-reactive $\mathrm{T}$ cells is suggested to occur within the meninges (37). While antigen-presenting phagocytic cells have been shown to productively interact with myelin-specific $\mathrm{T}$ cells in the subarachnoid space $(46,48-50)$, recent studies also demonstrate that meningeal stromal cells may be important for propagating encephalitogenic $\mathrm{T}$ cell responses within the CNS (52). With respect to meningeal B cell responses, class-switched memory B cells and plasmablasts/plasma cells have long been detected in the CSF of individuals with MS, and contribute to intrathecal production of antibodies, a hallmark of MS (43, 63). While antigen-experienced $B$ cells populate the meningeal compartment, clonally related B cells are also located in parenchymal lesions, the normal-appearing white matter (42), and in the periphery $(44,45,64)$, making it unclear where B cells are first primed. The presence of myelin antigens in the cLN of individuals with MS, but not healthy controls (65), and the discovery of lymphatics draining from the meningeal space to cLN (59) suggest that antigen-dependent B cell responses can be initiated in the cLN. Recently, deep sequencing analyses of the B cell receptor variable heavy chain $(\mathrm{VH})$ between matched CNS and peripheral samples demonstrated that upwards of $90 \%$ of founder B cell clones were localized within cervical lymph node tissues (44). However, it remains possible that the spatial-temporal distribution of founder clones differs at disease onset. In summary, the blood-CSF barrier is an important portal of entry for leukocytes into the CNS. The subarachnoid space represents an important site of accumulation for activated lymphocytes, as well as dendritic cells (46), neutrophils, and mast cells $(39,66)$ within the inflamed CNS.

\section{How Do TLT Form within the Meninges?}

The presence of immune cells in the meninges and CSF of individuals with MS does not in and of itself confirm that the meninges constitute an immune-competent niche. To endow "immune competence," such an environment would need to be populated by stromal support cells that secrete lymphocyte chemoattractants (such as CXCL13, CCL19, CCL21) and possibly also survival/differentiation factors (cytokines). Indeed, meningeal stromal cells have the capacity to secrete mediators such as TNF $\alpha$, iNOS, IL-6, TGF- $\beta$, and IL-23 under inflammatory conditions $(52,67)$. Pro-inflammatory cytokines themselves can induce lymphocytic accumulation within the meningeal compartment, as demonstrated following injection of TNF $\alpha$ and IFN $\gamma$ directly into the subarachnoid space (68) or intra-cortically (69) in rodents immunized sub-clinically with MOG. While these studies did 
not examine whether cytokine-induced TLT-like aggregates are supported by an underlying stromal cell and ECM network, TLT surrounded by a reticular network have been observed upon adoptive transfer of IL-17 producing encephalitogenic T cells in mice (24).

Expression of both $\mathrm{T}$ cell and $\mathrm{B}$ cell chemoattractants and lymphoid-like FRCs and FDCs has been demonstrated in the inflamed CNS. In both EAE and MS, CXCL13 expression and FDC-like cells $\left(\mathrm{CD}^{2} 5^{+}\right.$and $\left.\mathrm{FDC}-\mathrm{M1}^{+}\right)$are reported within $\mathrm{B}$ cell-rich meningeal aggregates $(2,36,40)$, while CCL19 and CCL21 transcripts have been detected within parenchymal and sub-meningeal lesions in the brains of SWR/J $\times \mathrm{SJL} / \mathrm{J}$ F1 mice with EAE (38). In the context of MS, over three decades ago, Prineas and colleagues described the presence of reticular-like cells embedded within lymphoid-like structures and lymphatic capillaries within old plaques in the MS CNS (70). While the phenotype of these reticular cells has not since been explored in the MS CNS, the elaboration and maturation of a reticular lymphoid-like stromal cell network were recently described in the brain meninges of mice with Th17 adoptive transfer EAE (52). FRC-like stromal cells were found to secrete pro-inflammatory cytokines, homeostatic chemokines (CXCL13, CCL21), as well as CXCL1 and BAFF, forming an immune-competent microenvironment. IL-17- and IL-22-derived signals were shown to promote the physical elaboration of the reticular network while acquisition of lymphoid-like stromal cell properties was in part lymphotoxin dependent, suggesting that multiple pathways culminate in the elaboration of an immune-regulatory stromal cell scaffold in the inflamed CNS. In summary, the meninges are a CNS environment poised to establish an inflammatory niche that is capable of supporting immune-responses within the CNS.

\section{Meningeal Inflammation and Cortical Pathology in MS}

Cortical lesions characterized by demyelination, axonal atrophy, and microglial activation in the sub-pial mater have been shown to underly meningeal lymphocytic infiltrates in the progressive MS CNS $(3,5,54)$, although another study failed to see a correlation between meningeal inflammation and sub-pial demyelination (71). The presence of meningeal TLT in SPMS correlates with accelerated clinical disease (earlier age of clinical onset, faster time of disease progression and earlier age of death) compared to SPMS cases without meningeal TLT (4).

\section{REFERENCES}

1. Revesz T, Kidd D, Thompson AJ, Barnard RO, McDonald WI. A comparison of the pathology of primary and secondary progressive multiple sclerosis. Brain (1994) 117(Pt 4):759-65. doi:10.1093/brain/117.4.759

2. Serafini B, Rosicarelli B, Magliozzi R, Stigliano E, Aloisi F. Detection of ectopic B-cell follicles with germinal centers in the meninges of patients with secondary progressive multiple sclerosis. Brain Pathol (2004) 14:164-74. doi: 10.1111/j.1750-3639.2004.tb00049.x

3. Magliozzi R, Howell O, Vora A, Serafini B, Nicholas R, Puopolo M, et al. Meningeal B-cell follicles in secondary progressive multiple sclerosis associate with early onset of disease and severe cortical pathology. Brain (2007) 130:1089-104. doi:10.1093/brain/awm038
It is postulated that soluble factors emanating from meningeal lymphocytic aggregates degrade the glial limitans, promoting a gradient of demyelination and neuronal injury $(3,6)$. While $\mathrm{B}$ cells, plasma cells $\left(\operatorname{IgA}^{+}, \operatorname{IgG}^{+}, \operatorname{IgM}^{+}\right), \mathrm{CD}^{+}$and $\mathrm{CD}^{+} \mathrm{T}$ cells, monocytes/macrophages infiltrate the subarachnoid space, a recent study revealed that only the accumulation of plasma cells and macrophages was significantly elevated in meningeal TLT compared to region-matched controls, and the accumulation of these particular cell types was associated with underlying cerebellar gray matter demyelination (41). In addition, the accumulation of meningeal $\mathrm{CD}^{+} \mathrm{T}$ cells correlates with axonal loss and microglial activation in the underlying normal-appearing white matter in the spinal cord in progressive MS (72). Taken together, these observations may reflect distinct susceptibility of different regions of the CNS to immune cell-mediated injury.

\section{CONCLUSIONS}

The presence and inducible formation of an immune-competent niche in the meninges suggests that these structures may support disease-relevant immune responses in the CNS. While TLT-associated immune responses are proposed to contribute to ongoing neuropathology and disease exacerbation, these structures likely evolve to support cell types regulating the balance of pro-inflammatory and anti-inflammatory responses in the meninges. Indeed, the accumulation of regulatory $\mathrm{T}$ cells within chronic aortic TLT is associated with clinical benefit in a rodent model of atherosclerosis (35). On the other hand, the presence of TLT in cases of enteropathic infection or cancer is associated with clinical benefit $(21,22,73,74)$. Therefore, one must consider that the cellular constituents of meningeal TLT may change over time, implicating altered neuropathological and clinical consequences within the inflamed CNS. We propose that an understanding of the cellular scaffolds that support lymphocyte retention within the meninges (i.e., specialized non-immune stromal cells) will lead to a better understanding of the meningeal compartment in the context of MS/EAE.

\section{FUNDING}

The authors wish to acknowledge the MS Society of Canada for an operating grant to JG, a team grant (Collaborative Grant on B cells and MS) to JG, AP and ABO, and a Doctoral student award to NP.

4. Howell OW, Reeves CA, Nicholas R, Carassiti D, Radotra B, Gentleman $\mathrm{SM}$, et al. Meningeal inflammation is widespread and linked to cortical pathology in multiple sclerosis. Brain (2011) 134:2755-71. doi:10.1093/ brain/awr 182

5. Choi SR, Howell OW, Carassiti D, Magliozzi R, Gveric D, Muraro PA, et al. Meningeal inflammation plays a role in the pathology of primary progressive multiple sclerosis. Brain (2012) 135:2925-37. doi:10.1093/brain/aws189

6. Magliozzi R, Howell OW, Reeves C, Roncaroli F, Nicholas R, Serafini B, et al. A gradient of neuronal loss and meningeal inflammation in multiple sclerosis. Ann Neurol (2010) 68:477-93. doi:10.1002/ana.22230

7. Absinta M, Vuolo L, Rao A, Nair G, Sati P, Cortese IC, et al. Gadolinium-based MRI characterization of leptomeningeal inflammation in multiple sclerosis. Neurology (2015) 85:18-28. doi:10.1212/WNL.0000000000001587 
8. Aloisi F, Pujol-Borrell R. Lymphoid neogenesis in chronic inflammatory diseases. Nat Rev Immunol (2006) 6:205-17. doi:10.1038/nril786

9. Carragher DM, Rangel-Moreno J, Randall TD. Ectopic lymphoid tissues and local immunity. Semin Immunol (2008) 20:26-42. doi:10.1016/j. smim.2007.12.004

10. Buckley CD, Barone F, Nayar S, Benezech C, Caamano J. Stromal cells in chronic inflammation and tertiary lymphoid organ formation. Annu Rev Immunol (2015) 33:715-45. doi:10.1146/annurev-immunol-032713-120252

11. Rodda LB, Bannard O, Ludewig B, Nagasawa T, Cyster JG. Phenotypic and morphological properties of germinal center dark zone Cxcl12-expressing reticular cells. J Immunol (2015) 195:4781-91. doi:10.4049/jimmunol.1501191

12. Chang JE, Turley SJ. Stromal infrastructure of the lymph node and coordination of immunity. Trends Immunol (2015) 36:30-9. doi:10.1016/j.it.2014.11.003

13. Drumea-Mirancea M, Wessels JT, Muller CA, Essl M, Eble JA, Tolosa E, et al. Characterization of a conduit system containing laminin-5 in the human thymus: a potential transport system for small molecules. J Cell Sci (2006) 119:1396-405. doi:10.1242/jcs.02840

14. Link A, Hardie DL, Favre S, Britschgi MR, Adams DH, Sixt M, et al. Association of T-zone reticular networks and conduits with ectopic lymphoid tissues in mice and humans. Am J Pathol (2011) 178:1662-75. doi:10.1016/j. ajpath.2010.12.039

15. Ruddle NH. Lymphatic vessels and tertiary lymphoid organs. J Clin Invest (2014) 124:953-9. doi:10.1172/JCI71611

16. Gommerman JL, Browning JL. Lymphotoxin/light, lymphoid microenvironments and autoimmune disease. Nat Rev Immunol (2003) 3:642-55. doi:10.1038/nri1151

17. Mebius RE. Organogenesis of lymphoid tissues. Nat Rev Immunol (2003) 3:292-303. doi:10.1038/nri1054

18. Drayton DL, Liao S, Mounzer RH, Ruddle NH. Lymphoid organ development: from ontogeny to neogenesis. Nat Immunol (2006) 7:344-53. doi:10.1038/ ni1330

19. Brendolan A, Caamano JH. Mesenchymal cell differentiation during lymph node organogenesis. Front Immunol (2012) 3:381. doi:10.3389/ fimmu.2012.00381

20. Koning JJ, Mebius RE. Interdependence of stromal and immune cells for lymph node function. Trends Immunol (2012) 33:264-70. doi:10.1016/j. it.2011.10.006

21. Ota N, Wong K, Valdez PA, Zheng Y, Crellin NK, Diehl L, et al. IL-22 bridges the lymphotoxin pathway with the maintenance of colonic lymphoid structures during infection with Citrobacter rodentium. Nat Immunol (2011) 12:941-8. doi:10.1038/ni.2089

22. Tumanov AV, Koroleva EP, Guo X, Wang Y, Kruglov A, Nedospasov S, et al. Lymphotoxin controls the IL-22 protection pathway in gut innate lymphoid cells during mucosal pathogen challenge. Cell Host Microbe (2011) 10:44-53. doi:10.1016/j.chom.2011.06.002

23. Hatfield JK, Brown MA. Group 3 innate lymphoid cells accumulate and exhibit disease-induced activation in the meninges in EAE. Cell Immunol (2015) 297(2):69-79. doi:10.1016/j.cellimm.2015.06.006

24. Peters A, Pitcher LA, Sullivan JM, Mitsdoerffer M, Acton SE, Franz B, et al. Th17 cells induce ectopic lymphoid follicles in central nervous system tissue inflammation. Immunity (2011) 35:986-96. doi:10.1016/j.immuni.2011.10.015

25. Rangel-Moreno J, Carragher DM, De La Luz Garcia-Hernandez M, Hwang JY, Kusser K, Hartson L, et al. The development of inducible bronchusassociated lymphoid tissue depends on IL-17. Nat Immunol (2011) 12:639-46. doi:10.1038/ni.2053

26. Fleige H, Ravens S, Moschovakis GL, Bolter J, Willenzon S, Sutter G, et al. IL-17-induced CXCL12 recruits B cells and induces follicle formation in BALT in the absence of differentiated FDCs. J Exp Med (2014) 211:643-51. doi:10.1084/jem.20131737

27. Barone F, Nayar S, Campos J, Cloake T, Withers DR, Toellner KM, et al. IL-22 regulates lymphoid chemokine production and assembly of tertiary lymphoid organs. Proc Natl Acad Sci U S A (2015) 112:11024-9. doi:10.1073/ pnas. 1503315112

28. Benezech C, Luu NT, Walker JA, Kruglov AA, Loo Y, Nakamura K, et al. Inflammation-induced formation of fat-associated lymphoid clusters. Nat Immunol (2015) 16:819-28. doi:10.1038/ni.3215

29. Peduto L, Dulauroy S, Lochner M, Spath GF, Morales MA, Cumano A, et al. Inflammation recapitulates the ontogeny of lymphoid stromal cells. J Immunol (2009) 182:5789-99. doi:10.4049/jimmunol.0803974
30. Grogan JL, Ouyang W. A role for Th17 cells in the regulation of tertiary lymphoid follicles. Eur J Immunol (2012) 42:2255-62. doi:10.1002/eji.201242656

31. Krautler NJ, Kana V, Kranich J, Tian Y, Perera D, Lemm D, et al. Follicular dendritic cells emerge from ubiquitous perivascular precursors. Cell (2012) 150:194-206. doi:10.1016/j.cell.2012.05.032

32. Malhotra D, Fletcher AL, Astarita J, Lukacs-Kornek V, Tayalia P, Gonzalez $\mathrm{SF}$, et al. Transcriptional profiling of stroma from inflamed and resting lymph nodes defines immunological hallmarks. Nat Immunol (2012) 13:499-510. doi:10.1038/ni.2262

33. Chai Q, Onder L, Scandella E, Gil-Cruz C, Perez-Shibayama C, Cupovic J, et al. Maturation of lymph node fibroblastic reticular cells from myofibroblastic precursors is critical for antiviral immunity. Immunity (2013) 38:1013-24. doi:10.1016/j.immuni.2013.03.012

34. Yang CY, Vogt TK, Favre S, Scarpellino L, Huang HY, Tacchini-Cottier F, et al. Trapping of naive lymphocytes triggers rapid growth and remodeling of the fibroblast network in reactive murine lymph nodes. Proc Natl Acad Sci U S A (2014) 111:E109-18. doi:10.1073/pnas.1312585111

35. Hu D, Mohanta SK, Yin C, Peng L, Ma Z, Srikakulapu P, et al. Artery tertiary lymphoid organs control aorta immunity and protect against atherosclerosis via vascular smooth muscle cell lymphotoxin beta receptors. Immunity (2015) 42:1100-15. doi:10.1016/j.immuni.2015.05.015

36. Magliozzi R, Columba-Cabezas S, Serafini B, Aloisi F. Intracerebral expression of CXCL13 and BAFF is accompanied by formation of lymphoid follicle-like structures in the meninges of mice with relapsing experimental autoimmune encephalomyelitis. J Neuroimmunol (2004) 148:11-23. doi:10.1016/j. jneuroim.2003.10.056

37. Kuerten S, Schickel A, Kerkloh C, Recks MS, Addicks K, Ruddle NH, et al. Tertiary lymphoid organ development coincides with determinant spreading of the myelin-specific T cell response. Acta Neuropathol (2012) 124:861-73. doi:10.1007/s00401-012-1023-3

38. Bielecki B, Jatczak-Pawlik I, Wolinski P, Bednarek A, Glabinski A. Central nervous system and peripheral expression of CCL19, CCL21 and their receptor CCR7 in experimental model of multiple sclerosis. Arch Immunol Ther Exp (Warsz) (2015) 63(5):367-76. doi:10.1007/s00005-015-0339-9

39. Walker-Caulfield ME, Hatfield JK, Brown MA. Dynamic changes in meningeal inflammation correspond to clinical exacerbations in a murine model of relapsing-remitting multiple sclerosis. J Neuroimmunol (2015) 278:112-22. doi:10.1016/j.jneuroim.2014.12.009

40. Columba-Cabezas S, Griguoli M, Rosicarelli B, Magliozzi R, Ria F, Serafini B, et al. Suppression of established experimental autoimmune encephalomyelitis and formation of meningeal lymphoid follicles by lymphotoxin beta receptor-Ig fusion protein. J Neuroimmunol (2006) 179:76-86. doi:10.1016/j. jneuroim.2006.06.015

41. Howell OW, Schulz-Trieglaff EK, Carassiti D, Gentleman SM, Nicholas R, Roncaroli F, et al. Extensive grey matter pathology in the cerebellum in multiple sclerosis is linked to inflammation in the subarachnoid space. Neuropathol Appl Neurobiol (2015) 41(6):798-813. doi:10.1111/nan.12199

42. Lovato L, Willis SN, Rodig SJ, Caron T, Almendinger SE, Howell OW, et al. Related B cell clones populate the meninges and parenchyma of patients with multiple sclerosis. Brain (2011) 134:534-41. doi:10.1093/brain/awq350

43. Obermeier B, Lovato L, Mentele R, Bruck W, Forne I, Imhof A, et al. Related B cell clones that populate the CSF and CNS of patients with multiple sclerosis produce CSF immunoglobulin. J Neuroimmunol (2011) 233:245-8. doi:10.1016/j.jneuroim.2011.01.010

44. Stern JN, Yaari G, Vander Heiden JA, Church G, Donahue WF, Hintzen RQ, et al. B cells populating the multiple sclerosis brain mature in the draining cervical lymph nodes. Sci Transl Med (2014) 6:248ra107. doi:10.1126/ scitranslmed.3008879

45. Palanichamy A, Apeltsin L, Kuo TC, Sirota M, Wang S, Pitts SJ, et al. Immunoglobulin class-switched B cells form an active immune axis between CNS and periphery in multiple sclerosis. Sci Transl Med (2014) 6:248ra106. doi:10.1126/scitranslmed.3008930

46. Greter M, Heppner FL, Lemos MP, Odermatt BM, Goebels N, Laufer T, et al. Dendritic cells permit immune invasion of the CNS in an animal model of multiple sclerosis. Nat Med (2005) 11:328-34. doi:10.1038/nm1197

47. Bartholomaus I, Kawakami N, Odoardi F, Schlager C, Miljkovic D, Ellwart $\mathrm{JW}$, et al. Effector T cell interactions with meningeal vascular structures in nascent autoimmune CNS lesions. Nature (2009) 462:94-8. doi:10.1038/ nature 08478 
48. Kivisakk P, Imitola J, Rasmussen S, Elyaman W, Zhu B, Ransohoff RM, et al. Localizing central nervous system immune surveillance: meningeal antigen-presenting cells activate $\mathrm{T}$ cells during experimental autoimmune encephalomyelitis. Ann Neurol (2009) 65:457-69. doi:10.1002/ana.21379

49. Lodygin D, Odoardi F, Schlager C, Korner H, Kitz A, Nosov M, et al. A combination of fluorescent NFAT and H2B sensors uncovers dynamics of T cell activation in real time during CNS autoimmunity. Nat Med (2013) 19:784-90. doi: $10.1038 / \mathrm{nm} .3182$

50. Mues M, Bartholomaus I, Thestrup T, Griesbeck O, Wekerle H, Kawakami N, et al. Real-time in vivo analysis of $\mathrm{T}$ cell activation in the central nervous system using a genetically encoded calcium indicator. Nat Med (2013) 19:778-83. doi: $10.1038 / \mathrm{nm} .3180$

51. Jager A, Dardalhon V, Sobel RA, Bettelli E, Kuchroo VK. Th1, Th17, and Th9 effector cells induce experimental autoimmune encephalomyelitis with different pathological phenotypes. J Immunol (2009) 183(11):7169-77. doi:10.4049/ jimmunol.0901906

52. Pikor NB, Astarita JL, Summers-Deluca L, Galicia G, Qu J, Ward LA, et al. Integration of Th17 and Lymphotoxin-derived signals initiates meningeal-resident stromal cell remodeling to propagate neuroinflammation. Immunity (2015) 43(6):1160-73. doi:10.1016/j.immuni.2015.11.010

53. Lucchinetti CF, Popescu BF, Bunyan RF, Moll NM, Roemer SF, Lassmann H, et al. Inflammatory cortical demyelination in early multiple sclerosis. $N$ Engl J Med (2011) 365:2188-97. doi:10.1056/NEJMoa1100648

54. Kutzelnigg A, Lucchinetti CF, Stadelmann C, Bruck W, Rauschka H, Bergmann $\mathrm{M}$, et al. Cortical demyelination and diffuse white matter injury in multiple sclerosis. Brain (2005) 128:2705-12. doi:10.1093/brain/awh641

55. Engelhardt B, Ransohoff RM. Capture, crawl, cross: the T cell code to breach the blood-brain barriers. Trends Immunol (2012) 33:579-89. doi:10.1016/j. it.2012.07.004

56. Zhang ET, Inman CB, Weller RO. Interrelationships of the pia mater and the perivascular (Virchow-Robin) spaces in the human cerebrum. J Anat (1990) 170:111-23.

57. Nonaka H, Akima M, Nagayama T, Hatori T, Zhang Z, Ihara F. Microvasculature of the human cerebral meninges. Neuropathology (2003) 23:129-35. doi:10.1046/j.1440-1789.2003.00487.x

58. Patel N, Kirmi O. Anatomy and imaging of the normal meninges. Semin Ultrasound CT MR (2009) 30:559-64. doi:10.1053/j.sult.2009.08.006

59. Louveau A, Smirnov I, Keyes TJ, Eccles JD, Rouhani SJ, Peske JD, et al. Structural and functional features of central nervous system lymphatic vessels. Nature (2015) 523:337-41. doi:10.1038/nature14432

60. Ransohoff RM, Engelhardt B. The anatomical and cellular basis of immune surveillance in the central nervous system. Nat Rev Immunol (2012) 12:623-35. doi: $10.1038 /$ nri3265

61. Matsumoto Y, Yoon WK, Jee Y, Fujihara K, Misu T, Sato S, et al. Complementarity-determining region 3 spectratyping analysis of the TCR repertoire in multiple sclerosis. J Immunol (2003) 170:4846-53. doi:10.4049/ jimmunol.170.9.4846

62. Junker A, Ivanidze J, Malotka J, Eiglmeier I, Lassmann H, Wekerle H, et al. Multiple sclerosis: T-cell receptor expression in distinct brain regions. Brain (2007) 130:2789-99. doi:10.1093/brain/awm214

63. Von Budingen HC, Bar-Or A, Zamvil SS. B cells in multiple sclerosis: connecting the dots. Curr Opin Immunol (2011) 23:713-20. doi:10.1016/j. coi.2011.09.003

64. Von Budingen HC, Kuo TC, Sirota M, Van Belle CJ, Apeltsin L, Glanville J, et al. B cell exchange across the blood-brain barrier in multiple sclerosis. J Clin Invest (2012) 122:4533-43. doi:10.1172/JCI63842
65. Fabriek BO, Zwemmer JN, Teunissen CE, Dijkstra CD, Polman CH, Laman JD, et al. In vivo detection of myelin proteins in cervical lymph nodes of MS patients using ultrasound-guided fine-needle aspiration cytology. $J$ Neuroimmunol (2005) 161:190-4. doi:10.1016/j.jneuroim.2004.12.018

66. Christy AL, Walker ME, Hessner MJ, Brown MA. Mast cell activation and neutrophil recruitment promotes early and robust inflammation in the meninges in EAE. J Autoimmun (2013) 42:50-61. doi:10.1016/j.jaut.2012.11.003

67. Wieseler-Frank J, Jekich BM, Mahoney JH, Bland ST, Maier SF, Watkins LR. A novel immune-to-CNS communication pathway: cells of the meninges surrounding the spinal cord CSF space produce proinflammatory cytokines in response to an inflammatory stimulus. Brain Behav Immun (2007) 21:711-8. doi:10.1016/j.bbi.2006.07.004

68. Gardner C, Magliozzi R, Durrenberger PF, Howell OW, Rundle J, Reynolds R. Cortical grey matter demyelination can be induced by elevated proinflammatory cytokines in the subarachnoid space of MOG-immunized rats. Brain (2013) 136:3596-608. doi:10.1093/brain/awt279

69. Merkler D, Ernsting T, Kerschensteiner M, Bruck W, Stadelmann C. A new focal EAE model of cortical demyelination: multiple sclerosis-like lesions with rapid resolution of inflammation and extensive remyelination. Brain (2006) 129:1972-83. doi:10.1093/brain/awl135

70. Prineas JW. Multiple sclerosis: presence of lymphatic capillaries and lymphoid tissue in the brain and spinal cord. Science (1979) 203:1123-5. doi:10.1126/ science. 424741

71. Kooi EJ, Geurts JJ, Van Horssen J, Bo L, Van Der Valk P. Meningeal inflammation is not associated with cortical demyelination in chronic multiple sclerosis. J Neuropathol Exp Neurol (2009) 68:1021-8. doi:10.1097/ NEN.0b013e3181b4bf8f

72. Androdias G, Reynolds R, Chanal M, Ritleng C, Confavreux C, Nataf S. Meningeal T cells associate with diffuse axonal loss in multiple sclerosis spinal cords. Ann Neurol (2010) 68:465-76. doi:10.1002/ana.22054

73. Martinet L, Garrido I, Filleron T, Le Guellec S, Bellard E, Fournie JJ, et al. Human solid tumors contain high endothelial venules: association with T- and B-lymphocyte infiltration and favorable prognosis in breast cancer. Cancer Res (2011) 71:5678-87. doi:10.1158/0008-5472.CAN-11-0431

74. Di Caro G, Bergomas F, Grizzi F, Doni A, Bianchi P, Malesci A, et al. Occurrence of tertiary lymphoid tissue is associated with T-cell infiltration and predicts better prognosis in early-stage colorectal cancers. Clin Cancer Res (2014) 20:2147-58. doi:10.1158/1078-0432.CCR-13-2590

Conflict of Interest Statement: Amit Bar-Or has participated as a speaker in meetings sponsored by and received consulting fees and/or grant support from Biogen Idec, Diogenix, Genentech, Sanofi-Genzyme, GlaxoSmithKline, Novartis, Ono Pharma, Teva Neuroscience, Receptos Inc., Roche, and Merck/EMD Serono. Jennifer Gommerman has received consulting fees from Novartis and Merck although these relationships bear no relevance to this mini-review. No other authors have financial relationships with entities that could be perceived to influence, or that give the appearance of potentially influencing, what the authors wrote in the submitted work.

Copyright (c) 2016 Pikor, Prat, Bar-Or and Gommerman. This is an open-access article distributed under the terms of the Creative Commons Attribution License (CC $B Y)$. The use, distribution or reproduction in other forums is permitted, provided the original author(s) or licensor are credited and that the original publication in this journal is cited, in accordance with accepted academic practice. No use, distribution or reproduction is permitted which does not comply with these terms. 